\title{
nature
}

\section{France's research base needs a shaking}

After years of failed reforms, the time is ripe for the French government to loosen rigidities within academic institutions and the CNRS. Top of the list are the terms of employment of young researchers.

T he collective sense of gloom and doom - "la morosité" — that has hung over France for the past decade seems to be lifting under the Prozac-like effect of the socialist government of Lionel Jospin. Scientists in particular are relieved to have escaped brutal cuts in public spending. Instead, the socialist victors have made education and research a priority, and increased the budget for civil research and development despite the difficult task of keeping the public deficit below the 3 per cent threshold needed to join the European single currency. A bigger psychological boost has come from the government's decision to create thousands of new full-time research posts in the research organizations and universities, ending years of stagnation in recruitment of young scientists.

The government's clear support for science has made scientists and their trade unions more open to the prospect of change. Claude Allègre, the education and research minister, has therefore bought himself a window of opportunity to bring about reform. Moreover, demographic trends indicate that the size of the student population is about to plummet, after decades during which universities were preoccupied with catching up with exponentially growing student numbers. As Allègre aptly asserts: "France has won the battle of quantity, now it is time to win the battle of quality".

Catherine Bréchignac, whom Allègre recently appointed as director general of the CNRS, last week announced an increase of almost one-tenth in funding for laboratory research, by taking money from big national physics facilities and strategic programmes (see page 895). This reflects Allègre's conviction that the balance between support for investigator-driven research and national wealth-creation strategies should favour the former, a policy that runs counter to the top-down tendencies elsewhere.

Although such moves will improve the lot of many scientists at the bench, they will not resolve the underlying structural problem repre- sented by the abysmally small sum that the CNRS is able to devote to research grants, given that its salary bill eats up more than threequarters of its total budget. Bréchignac's plans to increase competition for research grants - if they materialize - would mean that the sums available are spent more effectively, but it is clear that France could run a more productive and flexible research base by having fewer tenured scientists sharing the research-grant pie.

French scientists enjoy civil servant status: in other words, permanence that is enviable but which stifles competition, reduces mobility among researchers - there is no system of postdoctoral fellowships in France - and creates bloated and slow-moving bureaucracies. Neither Allègre nor many other French seem to want to tamper with the basic premise of life tenure. That principle (so long as it is sustainable) necessitates greater dirigisme on his part in enforcing mobility between different components of the government-funded research base. It is increasingly indefensible that researchers recruited to the CNRS should be guaranteed a lifetime career there. Better, surely, to change the terms of employment of new recruits so as to enable them to spend more of their later years teaching within the universities. Similarly, a robust system of postdoctoral fellowships could provide an efficient halfway house to permanent employment.

Grandiose policies to promote mobility have repeatedly failed, as can be judged by the fact that only a handful of researchers move each year between the research organizations, universities and industries. Will Allègre do any better? He knows well the full range of problems facing French research, and seems committed to implementing remedies through a policy of negotiated change rather than brusque upheaval imposed from above. Such an approach looks wise in exploiting researchers' current good will. But it should not become an excuse for inaction or half-measures in the face of the inevitable resistance to a much-needed shake-up.

\section{Univers ity reform overdue}

\section{Japan's higher educ ation institutions cannot carry on business as us ual.}

eaders of Japan's best universities have long maintained that their biggest problem is simply a lack of money compared with their counterparts in the West. If only the government would give them more funds, it is said, they will turn themselves into 'centres of excellence' in research and teaching through 'self-evaluation'.

Nothing could be further from the truth. Although Japan's best universities do harbour some brilliant researchers and teachers, they, like French institutions (see above), suffer from intellectual sclerosis caused by an existence that is too comfortable by half. They also need greater freedom from the bureaucratic strait-jacket placed on them by the education ministry and university administrators - who are often seconded from the ministry to ensure that the university stays in line with government policy.

The administrative reform council of the ruling Liberal Democ- ratic Party has made a radical proposal to meet the need for reform by converting some of Japan's national universities into more independent and accountable 'agencies' (see page 897). But the proposal has been quickly stamped on by the universities, the education ministry that oversees them, and Akito Arima, one of Japan's principal proponents of reform and external review. The universities are clearly concerned that such a move would deprive them of guaranteed government funding and will open them to public scrutiny, revealing the enormous waste that goes on in the system. There is also a genuine concern that Japan's universities are simply not ready for such drastic reform - they might be unable to cope with their new-found freedom. But if Japanese universities are truly to become world-class centres of excellence, they must accept healthy public scrutiny while taking on more responsibility for their financial affairs. 